\title{
Meanings Possessed by Gajah Oling Batik in Seblang Rituals Performed by Osing Tribe in Banyuwangi
}

\author{
Ike Ratnawati, Triyanto, Syakir
}

\begin{abstract}
Batik was originally used as an adiluhung (or noble) work for the royal palace's clothings and worn during traditional ceremonies or important events such as a wedding, a funeral, or birth and others. However, batik nowadays has no sacred values. Instead, it has become a commodity in a global market, and it results on making batik a profane value for daily needs of the society. Batik cannot be understood using its philosophical meanings and values unless by looking it back at the concept of space and time as it was originally created, to be used for traditional ceremonies and rituals. Seblang is one of the traditional rituals in Banyuwangi district which is still held and consistently uses Gajah Oling batik motif as one of its main devices. The study method used to explore and describe the socio-cultural background of batik used in Seblang ritual is qualitative research, supported by phenomenological theory approaches. Seblang is a ritual held once every year, in two different villages, and performed by an old woman or a girl in Bakungan village and Olehsari village respectively. Gajah Oling batik motif is worn by the performers of Seblang ritual as scarves, long clothes, and udeng(a headband).
\end{abstract}

Keywords: Batik, Seblang, Ritual.

\section{INTRODUCTION}

In almost all regions, especially in Java island,there are places or centers of batik crafting. In terms of its functions, batik is not only worn in sacred events or as clothings like shirts and sarung, but it has led to the fulfillment of a sense of beauty. Batik throughout Indonesia has unique and different characteristics, both in decorations and colors. However, it can be seen that there are similarities and differences between the batik from different regions. As a united country, although it consists of a variety of different ethnic groups and customs, Indonesia turns out to have similar tastes and images. If there are differences in style and taste in certain regions, it is because of their different belief, culture, and nature. This is in line with Koentjaraningrat who stated that the Indonesian's textile art identity is as follows: The art of crafts, especially weaving, batik art, tie-dye art, and textile art in Indonesia are branches of art that have been rooted in the country's culture for a long time, having high level in its

Revised Manuscript Received on September 22, 2019.

Ike Ratnawati, Doctoral Degree Program in Arts Education at Universitas Negeri Semarang. ike.ratnawati.fs@um.ac.id

Triyanto, Doctoral Degree Program in Arts Education at Universitas Negeri Semarang.triyanto@mail.unnes.ac.id

Syakir, Doctoral Degree Program in Visual Arts Department at Universitas Negeri Semarang. kirmuharrar@mail.unnes.ac.id.

beauty, and are able to highlight Indonesian's characters (Koentjaraningrat, 2005).

Batik which was originally a masterpiece for noble clothings and traditional rituals in Java, in its last development became an economic asset, which made the long philosophical values dissolved into market tastes. Batik cannot be comprehended by its meanings and philosophical values unless we look back at the concept of space and time as it was originally created. It was for traditional rituals. Likewise, in Banyuwangi district, Gajah Oling batik was originally used as a sacred function or a complement of Seblang ritual, also as a Gandrung dancers' costumes, for wedding attires, and for birth or burial ceremony. Nowadays, Gajah Oling batik is also used for profane functions both as Jebeng and Thole clothings, civil servants' uniforms, for school uniforms including kindergarten, elementary, middle and high school students, and also used for everyday's clothes. The shifting to the function of batik itself is influenced by economic, social, cultural factors, as well as market needs for batik.

Seblang is the oldest ritual in Banyuwangi district. It is performed to hold the society together. This performance of arts is an activity held as a social context which has symbolic systems expressed through the aesthetics on the body of a dancing old woman or a dancing girl wearing certain apparels and clothings as well. Batik Gajah Oling as the oldest batik in Banyuwangi district is one of the fashions that exists as a complement to the value of sacredness.

In this paper, the research questions are as follows: (1) How is the Seblang ritual in terms of the socio-cultural context seen in the Osing tribe located in Banyuwangi district? (2) How is Gajah Oling batik comprehended by the Osing tribe as it is used during the Seblang ritual?

\section{METHODOLOGY}

This study examines one of the arts in Banyuwangi district. The problem being studied is Banyuwangi's special batik motif called Gajah Oling batik which is used in Seblang rituals. The focus of the study is on attempts to identify qualitative understandings and explanations on these issues. According to (Rohidi, 2013), an art-related research is done through in-depth involvements of both the fields or real-life situations. 
Based on the theoretical frameworks presented, the methods used in this study include qualitative, holistic, integrative, descriptive, and qualitative analysis of the community's cultural phenomenon. Meanwhile, the research approach is phenomenological research, which refers to the subjective experience of the various subjects encountered. Phenomenological studies describe the general meaning of a number of individuals towards their life experiences related to concepts and phenomena.

The data needed in this study consisted of primary data and secondary data. In this study, the primary data sources were obtained from written sources, oral sources, and recordings. Secondary data sources consisted of people or artists who provided information as the second person or the one who comprehend the issues being explored, the relevant documents, and also the art performances or rituals related to the study.

In the implementation of this study, the data collection techniques used were observation techniques, interview techniques, and document engineering. The validity technique of data considered best suited to this research is the source triangulation technique. The three components of data analysis in qualitative research are data reduction, presentation of data, and conclusions drawn by verification. Qualitative data analysis model considered suitable to be used in this study is an interactive analysis model.

\section{FINDINGS}

Seblang is part of a culture which possesses a ritual systems and sacred values. In its context, Seblang is a space for social integrity which results on all members of the community having the same space and purpose in formulating their life (Heriyawati, 2016). As a cultural performance, Seblang is not only held as an effort to meet spiritual needs but it is also conducted in the fulfillment of human's physical and aesthetic needs. The symbols were selected and created to fulfill those needs.

The Seblang ritual is a dance performed by a possessed dancer who is unconscious (in trance). It is performed once every year in two different villages in Banyuwangi, namely Seblang Bakungan located in Bakungan village, and Seblang Olehsari which is located in Olehsari village. Seblang ritual is performed during the "Bersih Desa", an event with the aim of hoping for the safety of the village and its citizens. Seblang is the oldest and most potential ritual in Banyuwangi district, especially among Osing citizens, the native tribe of Banyuwangi district.

The costumes used for Seblang Bakungan and Olehsari dancers all use the Gajah Oling batik motif. The motif is used as a long cloth and a scarf by the panekep handler, pengrawit (the mastermind), and sinden (singer) with Gajah Oling motif in a white background. Meanwhile, the handler wears Udeng (headband) with Gajah Oling batik motif in black and white.

\section{RESULTS AND DISCUSSIONS}

Seblang ritual's performers include the dancers, handlers consisting of invited handler and panekep handler, omprog (head ornaments) maker, nine sinden and musicians. A Seblang dancer (an elderly woman who has reached menopause in Bakungan Village and a girl who is yet to experience menstruation in Olehsari village). The equipments for Seblang ritual are also quite varied which symbolize not only "umbo rampe" but also some spiritual values. The equipments used are omprog, genjot (a stage), musical instruments, offerings, perfumes, and costumes for the dancer, handlers, sinden, and the rest of the performers.
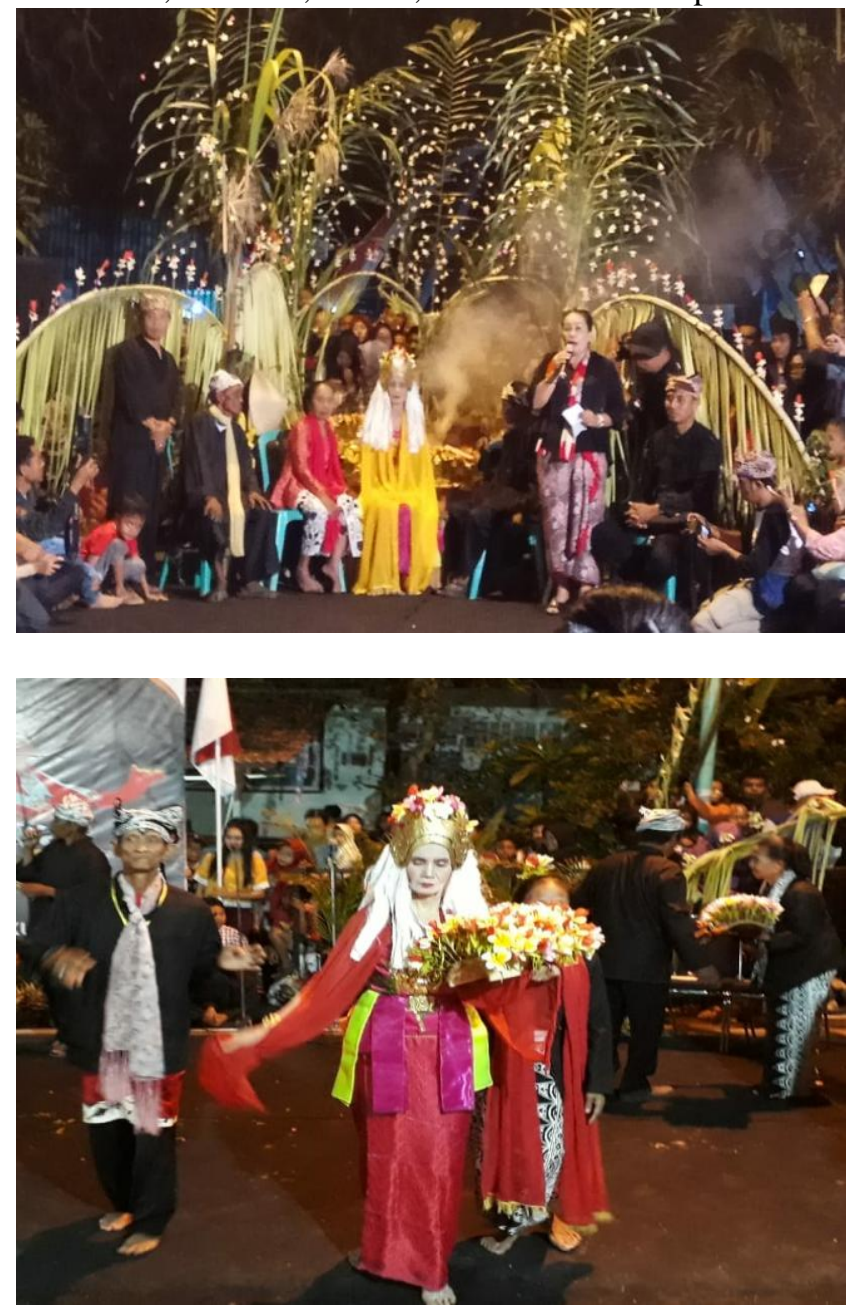

Fig 1. Seblang Bakungan Ritual (Source: Personal Collection, 2017)

The Seblang Bakungan ritual is started with "ider bumi", a ritual done by walking around the village on four cardinal directions or usually called "puju desa". In each of the "puju desa", there is a "site" that is believed to be the location where the ancestors live or where the "water sources" exist. After the "ider bumi", the dancer will head to the studio or stage while she is dancing the 12 songs performed as a parody or story. After completing the songs, the dancer ends the performance in front of the studio. She is then flanked by the handler and the shaman on the right and the left side respectively in order to cast some spells. 


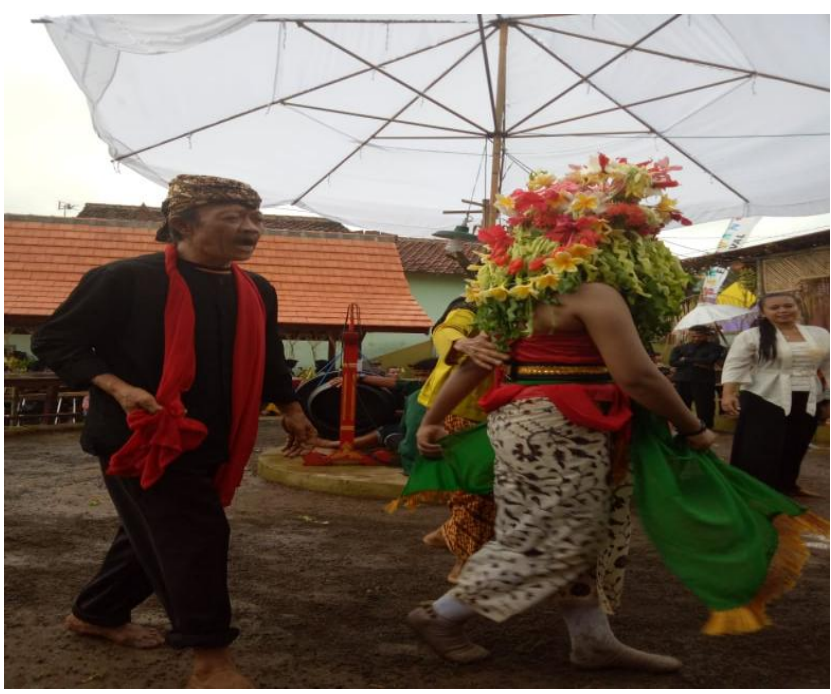

Fig 2. Seblang Olehsari Ritual (Source: Personal Collection, 2018)

Meanwhile, as in Seblang Olehsari ritual, the researcher has concluded some important points taken from Hasnan Singodimajan's statement which is as follows. Firstly, the dancer is marched from the omprog maker's house, dressed and in make ups. The dancer is flanked by the invited handler and the shaman then together with the sinden they are walking to the stage while covered with a yellow umbrella. Arriving at the dancer's stage, she is taken to the prepared seat. Then, the handler casts the spells, wears the omprog on his head, and closes the eyes of the dancer. This is quite stressful moment because it will involve the process of trance in which the dancer's body will be possessed by an outer spirit. When the 'nyiru' falls down from her grip, the dancer will follow the music and she start to dance. Occasionally, the dancer will stop dancing at a certain position and pay tribute to the audience by nodding and shaking hands. This dance is accompanied by 27 songs sung by the sinden (Singodimajan, 2019).

\section{A. Gajah Oling Batik Motif Is Understood by The Osing Tribe as A System of Values in Seblang Ritual}

Seblang ritual is always related to social life in a community. It means that Seblang ritual was born from the community, as well as made and used by the community. In this case, the community is the Osing tribe. In its context, Seblang is related to social systems (ecomony, politics, technology, and trust). This ritual is also related to the public's belief in the spirits, the vertical relationship between a man and his God. It is the combination of religious and cultural rituals. A ritual is used to create a communication between human and the unseen or spirits, deliver various requests or prayers, and achieve peace and prosperity in a society. That is why Gajah Oling batik is believed by the Banyuwangi citizens as the oldest motif or considered as the most sacred of any other motifs, so that this batik motif is always continuously used on the Seblang rituals either as a long cloth and udeng.

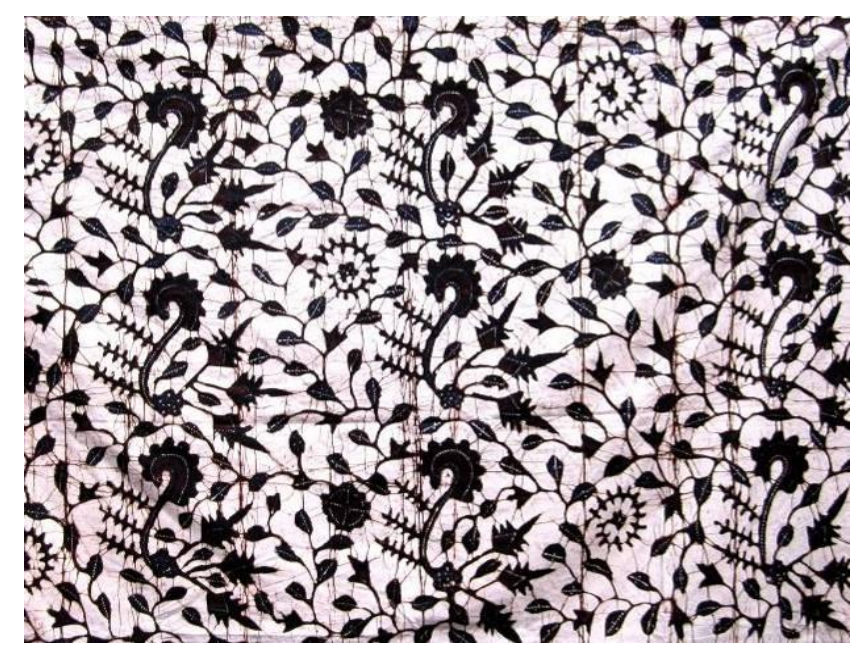

Fig 3. Gajah Oling Batik Motif

In ancient times, Princess Sayuwiwit danced Seblang while wearing Gajah Oling batik motif in black and white, but now its color has changed. In Seblang Bakungan, the color of Gajah Oling batik now uses red-brown, and in Seblang Olehsari it is green-yellow. There are three colors considered as the ritual colors or ancient ones; they are red, black, and white. In batik term, the color can be said as brownish-red, bluish-black, and yellowish-white. This is in accordance with the statement of Jakob Sumardjo in the book entitled Estetika Paradoks as follows:

Black, white, and red are the common colors in pre-modern era of Indonesia. It was originally a symbol of the sky (the upper world), which was white or yellow, and red symbolizes the human world (or the middle world), and black symbolizes the underworld. In batik, the three colors become white, blue, or bluish black, and brown (or red). In the era of Hinduism in Java, the meanings of the three colors had changed, in which they symbolized Lord Brahma (red), the Lord Vishnu (black), and Lord Shiva (white), as seen on the complex of Prambanan Temple. But perhaps those colors may still carry the Indonesian primordial symbols (Sumardjo, 2006).

The costume worn by the Seblang Olehsari dancer is almost identical to the costume of the dancer in Seblang Bakungan. Gajah Oling batik motif worn by Seblang dancers uses a white background with black motifs, but sometimes it also uses green background with yellow and red motifs. They also use Gajah Oling batik motif for the sinden and handlers. For sinden (the singer), pengrawit (the mastermind), and pawang panekep (the handler), Gajah Oling batik with white background and black motifs are used as long clothes and selendang (shawl). Meanwhile, for the handler, Gajah Oling batik motif is used for udeng (headband).

\section{REFERENCES}

[1] Heriyawati, Y. (2016). Seni Pertunjukan dan Ritual. Yogyakarta: Ombak.

[2] Kartika, Dharsono Sony. 2007. Budaya Nusantara. Bandung: Rekayasa Sains.

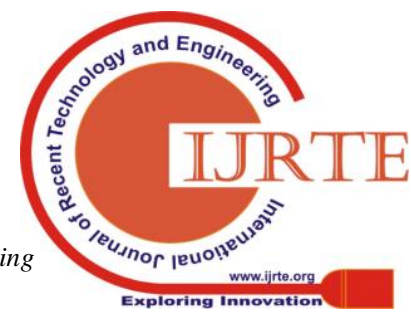


[3] Koentjaraningrat. (2005). Pengantar Antropologi. Jakarta: Rineka Cipta.

[4] Prasetyo, Azhar. 2007. Batik Banyuwangi. Banyuwangi: Dewan Kesenian Blambangan

[5] Rohidi, T. (2013). Metode Penelitian Seni. Semarang: Cipta Prima Nusantara.

[6] Singodimajan, H. (2019). Ritual Adat Seblang Sebagai Seni Perdamaian Masyarakat Using Banyuwangi. Banyuwangi: Dinas Kebudayaan dan Pariwisata Kabupaten Banyuwangi.

[7] Sumardjo, J. (2006). Estetika Paradoks. Bandung: Sunan Ambu press.

[8] Sutarto, Ayu dan Sudikan, Setya Yuwana. 2008. Pemetaan Kebudayaan di Propinsi Jawa

[9] Timur. Jember: Biru Mental Spiritual Jatim dan Kompyawisda Jatim.

[10] Tanpa Nama. 2009. Gendhing-gendhing Mantra Seblang Olehsari. Banyuwangi: Dinas Kebudayaan dan Periwisata Kabupaten Banyuwangi.

[11] Van Der Hoop. 1949. Ragam-ragam Perhiasan Indonesia. Jakarta: Koninklijk Bataviaasch Genootshap Van Kunsten En Wetenschappen.

\section{AUTHORS PROFILE}

I am Ike Ratnawati, I am associated with Doctoral Degree Program in Arts Education at Universitas Negeri Semarang. My area of interest is education.

My name is Triyanto, perusing Doctoral Degree Program in Arts Education at Universitas Negeri Semarang. My area of interest is education.

My name is Syakir, I am perusing Doctoral Degree Program in Visual Arts Department at Universitas Negeri Semarang. My area of interest is education. My area of interest is education. 